\title{
МЕТОДОЛОГІЧНИЙ БАЗИС УПРАВЛІННЯ ОРГАНІЗАЦІЙНО-ПРАВОВОЮ БЕЗПЕКОЮ СУБ'ЄКТІВ АГАРНОГО БІЗНЕСУ
}

\author{
Сьомич Микола Іванович \\ кандидат наук з державного управління, доцент \\ Полтавська державна аграрна академія Міністерства освіти і науки України
} ORCID: 0000-0001-7049-9992

\begin{abstract}
Стаття присвячена обгрунтуванню методологічного базису управління організаційно-правовою безпекою суб'єктів аграрного бізнесу. Розглянуто розуміння управління з точки зору кібернетики. Визначена роль стейкхолдерів у здійсненні управління організаційно-правовою безпекою. Розглянуті підходи до управління економічною безпекою підприємства: ресурсно-фуннціональний, управління відносно захисту інтересів підприємства, гармонізаційний підхід, контролюючий підхід, з позицій корпоративної культури й ефективного корпоративного управління. Визначено, що методологічний базис виступає основою управління. Запропоновано множину загальних і спещифрічних принципів управління організаційноправовою безпекою.

Запропоновано функції управління організаційно-правової безпекою: прогнозування, планування, організації, мотивації, контролю. Розглянуто та обгрунтовано зміст методів в рамках методологічного базису, до яких віднесено організаційно-адміністративні, економічні, соціально-психологічні. Також виокремлено загальнонаукові і прикладні методи. Прикладні методи розподілено на інституційно-правові, адміністративні, економічні, організаційно-технологічні, інформаційні, соціально-психологічні.
\end{abstract}

Ключові слова: організаційно-правова безпека, суб’єкти аграрного бізнесу, методологічний базис, методи, фрункції, принщипи.

DOI: https://doi.org/10.32845/bsnau.2019.4.11

Постановка проблеми. В класичному кібернетичному розумінні управління - це процес впливу суб'єкта управління на об'єкт з метою переведення останнього у бажаний стан. Бажаним станом виступає рівень організаційно-правової безпеки, який відображає стратегічне бачення підприємства, узгоджений із зацікавленими сторонами відносно сукупності заходів, плану їх реалізації та витрат, необхідних для їх впровадження. Безпосереднім об'єктом виступають процеси здійснення суб'єктом аграрного бізнесу поточної діяльності, які стосуються взаємодії із зацікавленими сторонами відносно задоволення їх потреб, врахування інтересів і збереження цінностей. Метою підприємства як системи в даному випадку виступає збереження непорушних прав власності на активи підприємства, цілісності та недоторканості майна, можливості вільно здійснювати підприємницьку діяльність без обмеження свобод конкурентних дій в рамках законодавства. В якості суб'єкта виступає менеджмент підприємства, але враховуючи розроблену та запропоновану автором концепцію організаційно-правової безпеки [1], яка базується на положеннях теорії зацікавлених сторін, має місце розподіл функцій впливу між іншими суб'єктами. В рамках ієрархії повноважень роль інших стейкхолдерів відносно забезпечення організаційно-правової безпеки є підпорядкованою керівництву підприємства, так як тільки воно безпосередньо переслідує цілі, властиві підприємству як економічній системі. Отже, при перерозподілі впливу на процеси функціонування підприємства, які опосередковують сфери організаційно-правової безпеки, суб'єктами можуть виступати інші стейкхолдери. Найбільш потужним потенціалом в даному розумінні володіють власники та акціонери, так як найзначніші загрози традиційно стосується майна, здатності здійснювати господарську діяльність і відповідно отримувати прибуток, що в першу чергу торкається інтересів цієї зацікавленої сторони. Вплив робітників підприємства стосується належного рівня відповідальності

щодо забезпечення необхідного рівня якості продукції та трудової дисципліни, ссрери яких найчастіше виступають загрозами безпеці. Роль фінансових установ як суб'єкта є обмеженою. Натомість органи державної влади, правоохоронні органи та суб'єкти недержавної системи безпеки, які спеціалізуються на інформаційно-аналітичного забезпечення, $€$ активними зовнішніми суб'єктами, роль яких зазначена в роботі [2].

Аналіз останніх досліджень і публікацій. В основу дослідження покладено праці у галузі безпекології та управління економічною безпекою, де вагомі наукові результати отримано такими вченими як: Г. Атамановою, Д. Буркальцевою, Т. Васильцівим, В. Вахлаковою, В. Гейцем, С. Ілляшенком, О. Ляшенком, М. Караїм, М. Кизимом, А. Козаченко, Я. Маликом, О. Маслаком, О. Марченко, І. Мойсеєнко, Є. Овчаренком, О. Россошанською, С. Шкарлетом, Л. Шемаєвою, Л. Шульженко. Проблемні питання економічного захисту та дотримання безпеки основної діяльності аграрних підприємств висвітлені у працях таких вітчизняних вчених як: О. Амосова, В. Андрійчука, Ю. Данька, М. Дем'яненка, О. Єрмакова, М. Ігнатенка, О. Іваницької, І. Крюкової, Т. Лепейко, Ю. Лупенка, М. Маліка, В. Мартиненка, І. Маркіної, Л. Мармуль, В.Онегіної, А. Пересади, Г. Черевка.

Мета статті. Розробити методологічний базис управління організаційно-правовою безпекою суб'єктів агарного бізнесу ґрунтуючись на класичних положеннях безпекології.

Виклад основного матеріалу. У сфері організаційно-правової безпеки науково-методологічний інструментарій управління нею через високий рівень новизни фактично не розроблений, тож варто оглядово розглянути підходи до управління економічною безпекою.

Найбільш розповсюдженими серед підходів до розуміння змісту управління безпекою підприємства $є$ ресурснофункціональний, зміст якого полягає у використанні наявних ресурсів, включаючи підприємницькі можливості, найбільш 
ефективним шляхом для ліквідації, послаблення або недопущення загроз і забезпечення стабільного функціонування підприємства [3-7]. Наступним підходом є управління відносно захисту інтересів підприємства, який передбачає захист інтересів суб'єкта господарювання від внутрішніх і зовнішніх загроз, що передбачає здатність протистояти ним і забезпечувати стабільність функціонування [8]. В більш розширеному варіанті захист інтересів представлений як міра гармонізації в часі і просторі економічних інтересів з інтересами пов'язаних суб'єктів зовнішнього по відношенню до підприємства середовища [9]. Як бачимо ці підходи близькі до концепції зацікавлених сторін, але їх відчутним недоліком є відсутність конкретного уточнення сторін характеру досягнення збалансованості або врахування лише зовнішнього середовища.

Акцент на окремих видах діяльності, представлених обліково-аналітичними та контрольними процедурами для оптимізації використання корпоративних ресурсів підприємства для нівелювання загроз представлена в роботі [1], яка відображає зміст контролюючого підходу. Його недоліком є обмеженість сфери вузькими групами функції управління, так як повноцінний ефект від здійснення управління організаційно- правовою безпекою можна отримати лише в разі реалізації всієї множини функцій, представлених плануванням, організацією, мотивацією, контролем, регулюванням і прогнозування, де функції обліку та моніторингу включені до змісту функції контролю.

Альтернативним підходом $€$ розгляд забезпечення безпеки аграрних підприємств з позиції корпоративної культури й ефективного корпоративного управління [10, с. 68].

Методологічний базис виступає основою управління, що обґрунтовує потребу в детермінації його структури. Найчастіше в структуру методологічного базису відносять принципи, функції, методи та стратегії, розроблення яких відносно змісту організаційно-правової безпеки є обов'язковим в контексті формування ії̈ забезпечення.

Велика увага приділяється обґрунтуванню принципів управління безпекою. На основі узагальнення чисельних досліджень $[1,11-15]$ варто запропонувати зміст принципів управління організаційно-правовою безпекою суб'єктів аграрного бізнесу, які об'єднані в дві групи: загальні та специфічні. Розглянемо детально зміст групи загальних принципів (таблиця 1).

Таблиця 1

Зміст загальних принципів управління організаційно-правовою безпекою

\begin{tabular}{|c|c|}
\hline Принцип & Зміст \\
\hline Принцип законності & $\begin{array}{l}\text { Необхідність дотримання діяльності суб’єктів аграрного бізнесу виключно у правовому полі відповідно діючій } \\
\text { системі законодавства. Зміст даного принципу варто розширити, включивши до нормативних документів пра- } \\
\text { вила корпоративного устрою та соціальної відповідальності [16]. Це обгрунтовано внутрішньою складовою орга- } \\
\text { нізаційно-правової безпеки відповідно розробленій у попередніх підрозділах моделі оцінювання. Якщо керівни- } \\
\text { цтво підприємства виключно «декларує» внутрішні правила, не дотримуючись них, - це створює загрозу сприй- } \\
\text { няття персоналом спільних цінностей, що звужує потенційну сфееру реалізації захисту інтересів, потреб і цінно- } \\
\text { стей організаційно-правової безпеки. }\end{array}$ \\
\hline Принцип системності & $\begin{array}{l}\text { Передбачає необхідність реалізації захисту в обох сферах за їх структурою в рамках ментальної карти, що до- } \\
\text { зволить досяпти додаткового ефекту від встановлених взаємозв'язків між цими підсферами в забезпеченні інте- } \\
\text { ресів, цінностей і потреб зацікавлених сторін, недоторканності та цілісності майна, свободи здійснення підпри- } \\
\text { ємницької діяльності. }\end{array}$ \\
\hline $\begin{array}{l}\text { Принцип } \\
\text { обґрунтованості }\end{array}$ & $\begin{array}{l}\text { Варто визначити як створення внутрішньої бази даних «тригерів» - як опису загроз із усіма їх характеристиками } \\
\text { для використання в поточній управлінській діяльності. Також цей принцип передбачає застосування інструмен- } \\
\text { тарію економіко-математичного та імітаційного моделювання процесів для аналізу можливих сценаріїв розвитку } \\
\text { подій з метою розробки стратегій ефективної реакції на них. }\end{array}$ \\
\hline $\begin{array}{l}\text { Принцип } \\
\text { своєчасності }\end{array}$ & $\begin{array}{l}\text { Є однозначним, виходячи з його назви, який передбачає своєчасність розробки іприйняття заходів нейтралізації } \\
\text { загроз та/або їх недопущення, включаючи множину попереджувальних профрілактичних заходів, а також елеме- } \\
\text { нти швидкого антикризового регулювання. Крім цього передбачається рання постановка завдань при впрова- } \\
\text { дженні системи організаційно правової безпеки на основі аналізу та моніторингу внутрішніх і зовнішніх процесів. }\end{array}$ \\
\hline $\begin{array}{l}\text { Принцип } \\
\text { комплексності }\end{array}$ & $\begin{array}{l}\text { Розглядається або як залучення всіх наявних ресурсів для протидії загрозам, або в контексті вза } \\
\text { безпеки й особливості його функціонування, або в контексті залучення всіх суб'єктів і активів пі } \\
\text { ховуючи зміст поняття комплекс, беручи до уваги вищенаведений зміст принципу системності } \\
\text { сне бачення виділених складових в їх постійній взаємодії для забезпечення захисту від всіх мс }\end{array}$ \\
\hline $\begin{array}{l}\text { Принцип } \\
\text { збалансованості }\end{array}$ & $\begin{array}{l}\text { передбачає врахування інтересів окремих підрозділів підприємства, відділів і інших структурних одиниць в ор- } \\
\text { ганізаційно-правовій безпеці. }\end{array}$ \\
\hline $\begin{array}{l}\text { Принцип } \\
\text { безперервності }\end{array}$ & $\begin{array}{l}\text { Полягає у постійному розробленні та впровадженні заходів забезпечення організаційно-правової безпеки підп- } \\
\text { риємства, що вимагає розробки довгострокових планів. }\end{array}$ \\
\hline $\begin{array}{l}\text { Принцип } \\
\text { економічності } \\
\text { економічної } \\
\text { доцільності }\end{array}$ & $\begin{array}{l}\text { Передбачає необхідність перевищення отриманих корисних результатів від впровадження системи організації } \\
\text { організаційно-правової безпеки, витрат на заходи ї̈ забезпечення над витратами, які підприємства може поне- } \\
\text { сти в разі настання впливу загроз у формі фактичних втрат. Проведення цих розрахунків має відповідати масш-- } \\
\text { табу бюджету підприємства - тобто співставлення вигід і витрат має здійснюватися відносно самих себе та від-- } \\
\text { носно бюджету підприємства. В контексті економічної безпеки витрати мають оцінюватися у фактичній та альте- } \\
\text { рнативній форми: доцільно враховувати не лише можливі фактичні збитки, але й недоотримання прибутку. В } \\
\text { організаційно-правовій безпеці оцінюються виключно можливі фактичні збитки та втрати. }\end{array}$ \\
\hline $\begin{array}{l}\text { Принцип } \\
\text { есрективності } \\
\text { управлінських рішень }\end{array}$ & $\begin{array}{l}\text { Передбачає виділення управлінського впливу в організаційно-правовій безпеці відносно сфер її захисту. } \\
\text { Прийняті рішення мають відповідати поставленим цілям і визначеним витратам на їх досягнення. }\end{array}$ \\
\hline $\begin{array}{l}\text { Принцип } \\
\text { цілеспрямованості }\end{array}$ & $\begin{array}{l}\text { ться сутністю програмно-цільового управління, а ціли організаційно-правової безпеки мають узгоджу- } \\
\text { цілями інших сфер безпеки суб'єктів аграрного бізнесу та стратегії його розвитку. Для розробки якісних } \\
\text { диційним є використання Smart-методу. }\end{array}$ \\
\hline
\end{tabular}

Вісник Сумського національного аграрного університету

Серія «Економіка і менеджмент», випуск 4 (82), 2019 
Продовження табл. 1

\begin{tabular}{|c|c|}
\hline Принцип & Зміст \\
\hline $\begin{array}{l}\text { Принцип } \\
\text { об'єктивності }\end{array}$ & $\begin{array}{l}\text { Полягає у сприйнятті об'єкта управління в усій його багатогранності, складності, суперечливості та динамічності, } \\
\text { враховуючи об'єктивні закони взаємодії його підсистем, з використанням наукових методів пізнання (аналізу та } \\
\text { синтезу, індукції та дедукції) без врахування власної точки зору суб'єкта управління. }\end{array}$ \\
\hline $\begin{array}{l}\text { Принцип } \\
\text { динамічності }\end{array}$ & $\begin{array}{l}\text { Передбачає врахування необхідності поступової зміни концепції управління організаційно-правовою безпекою } \\
\text { підприємства під впливом динаміки зовнішнього середовища, тенденцій руху всередині підприємства, монітори- } \\
\text { нгу стану ідентиффікованих загроз і сучасних політик у сфері безпекології. }\end{array}$ \\
\hline $\begin{array}{l}\text { Принцип } \\
\text { адаптивності }\end{array}$ & $\begin{array}{l}\text { Стосується здатності системи управління організаційно-правової безпеки пристосовуватися до змін зовнішнього } \\
\text { та внутрішнього оточення суб'єкт аграрного бізнесу з метою уникнення загроз. }\end{array}$ \\
\hline Принцип гнучкості & $\begin{array}{l}\text { Має відображати внутрішню структуру управління організаційно-правовою безпекою, яка дозволяє без відчутної } \\
\text { шкоди її стабільності вносити зміни в хід ї̈ фуннкціонування, вдосконалюючи управлінські процеси, оптимізуючи } \\
\text { взаємодію, що дозволить забезпечити вищезазначену швидкість реакцій на загрози. }\end{array}$ \\
\hline Принцип взаємодії & $\begin{array}{l}\text { Стосується організації заходів щодо забезпечення організаційно-правової безпеки, включаючи всі підрозділи } \\
\text { підприємства із здійсненням централізованого управління, включаючи взаємодію з державними та охоронними } \\
\text { установами. }\end{array}$ \\
\hline Принцип достатності & $\begin{array}{l}\text { Передбачає реалізацію ефективних заходів забезпечення організаційно-правової безпеки, найсучасніших мето- } \\
\text { дів або моделей в залежності від рівня загроз та небезпеки. }\end{array}$ \\
\hline $\begin{array}{l}\text { Принцип } \\
\text { конвергентності }\end{array}$ & $\begin{array}{l}\text { Стосується застосування різних індукційних методів пошуку об'єктивного кінцевого результату управління орга- } \\
\text { нізаційно-правової безпекою підприємства }\end{array}$ \\
\hline $\begin{array}{l}\text { Принцип повноти і } \\
\text { достовірності } \\
\text { інформації }\end{array}$ & $\begin{array}{l}\text { Стосується налагодження відповідного інформаційного забезпечення на протязі всього періоду, на всіх етапах } \\
\text { прийняття управлінських рішень у сфрері організаційно-правової безпеки. }\end{array}$ \\
\hline $\begin{array}{l}\text { Принцип } \\
\text { централізації } \\
\text { управління }\end{array}$ & $\begin{array}{l}\text { Передбачає функціонування системи організаційно-правової безпеки за єдиними принципами із централізова- } \\
\text { ним керуванням діяльністю системи і методичним забезпечення з боку відповідного підрозділу, а також дотри- } \\
\text { мання єдиного підходу до виконання функцій всіх учасників процесу забезпечення. }\end{array}$ \\
\hline $\begin{array}{l}\text { Принцип } \\
\text { пріоритетності }\end{array}$ & $\begin{array}{l}\text { стосується ранжування цілей і завдань у відповідності до вибраної концепції управління організаційно-правової } \\
\text { безпекою. }\end{array}$ \\
\hline
\end{tabular}

Група специфічних принципів представлена таким складом. Принцип активності передбачає захист інтересів, потреб та цінностей зацікавлених сторін при реалізації заходів організаційно-правової безпеки при високому ступені наполегливості, використовуючи стандартні та нестандартні методи. Принцип постійного моніторингу стосується реалізації даної функції відносно зовнішнього середовища для своєчасного виявлення та ідентифікації загроз. Принцип координації тісно пов'язаний із взаємодією та централізацією, зміст якого полягає в координації зусиль всіх суб'єктів організаційно-правової безпеки відповідно поставленим цілям та завданням з єдиного центру, а також розробки стандартів вимірювання фактичних результатів та встановлення дій в разі порушення гранично допустимих норм відхилень від запланованих. Принцип інтегрованості стосується вбудовування системи управління організаційно-правовою безпекою в загальну систему менеджменту підприємства. Принцип варіативності стосується розробки альтернативних варіантів стратегії в залежності від сценаріїв розвитку подій відносно можливих загроз організаційно-правові безпеці підприємства. Принцип адекватності реагування передбачає необхідність визначення критеріїв вибору заходів реагування на загрози цінностям, потребам та інтересам зацікавлених сторін в забезпеченні організаційно-правової безпеки.

Принцип стимулювання і відповідальності стосується існуючої системи мотивації у суб'єктів аграрного бізнесу разом із відповідальністю керівників щодо реалізація організаційно-правової безпеки [17].

Принцип утримання стійкості стосується забезпечення функціонування підприємства за умов виникнення загроз організаційно-правовій безпеці, що вимагає належного рівня забезпеченості процесів управління.
Принцип моделювання управління є комплексним і охоплює ряд складових [18]. Під організаційним моделюванням варто розуміти частину управлінської діяльності, яка спрямована на визначення оптимальних моделей, систем управління, їх основних якостей, критеріїв, характеристик, параметрів відносин процесів, ефективних з точки зору реалізації поставлених завдань, що передбачає втілення в процесі діяльності та вираження їх у певній знаковій формі. Другою складовою принципу моделювання управління є оптимальне зіставлення централізації та децентралізації.

Принцип участі працівників в управлінні, що стосується специфіки організаційно-правової форми діяльності суб'єкт аграрного бізнесу, особливо в розрізі розподілу отриманого прибутку. Для кожної організаційно-правової форми включення працівників до управління дозволяє створити єдність бачення місії, цілі та напрямків руху підприємства, що розширює сферу спільних цінностей в забезпеченні організаційно-правової безпеки. Останній елемент стосується делегування і відповідальності щодо передачі завдань управління організаційно-правовою безпекою відповідальній особі.

Принцип пріоритету заходів попередження стосується першочергового впровадження заходів вранішнього недопущення настання впливу загроз на діяльність суб'єкта аграрного бізнесу у порівнянні із заходами нівелювання їх негативного впливу або антикризової програми дій організаційноправової безпеки. Принцип спеціалізації стосується залучення в реалізацію заходів організаційно-правової безпеки відповідних спеціалізованих організацій, а також використання технічних засобів кваліфікованими фахівцями. Це стосується пошуку інформації щодо доброчесних постачальників або покупців через спеціалізовані установи.

На відміну від традиційного розуміння принципу прийнятного ризику серед дослідників [18; 19] (через неможли- 
вість виконання критерію не перевищення визначеної допустимої межі) його варто розуміти як окрему суму збитків, яку підприємство готово понести в ході своєї діяльності в разі виникнення загроз та несприятливих втрат від їх впливу через незначний розмір зазначених втрат.

Принцип диференційованості полягає у виборі заходів подолання або попередження загроз організаційно-правовій безпеці в залежності від ступеня тяжкості їх наслідків.

Принцип циклічності базується на процесі повторюваності процедур, які реалізують заходи управління організаційно-правовою безпекою суб'єктів аграрного бізнесу [16]. Це дозволяє перейти до власних стандартів управління, знижуючи таким чином витрати на забезпечення управління та підвищення його якості.

Останнім серед специфічних є принцип узгодженості інтересів, який виступає ключовим та об'єднуючим в розрізі прийняття за базову в забезпеченні організаційно-правової безпеки концепцію управління зацікавленими сторонами.

Запропоновані принципи являють собою множину тісно взаємопов'язаних елементів управління організаційноправовою безпекою, реалізація яких на практиці залежить від типу і характеру загроз, наявності фінансових і інших ресурсів у підприємства, рівня компетентності керівних кадрів, прийнятої політики на підприємстві відносно реалізації функції безпеки, динаміки зовнішнього середовища й стану протікання процесів в господарській діяльності суб'єкт аграрного бізнесу.

Наступним блоком методологічного базису варто визнати множину функцій управління, яка об'єднує групи дії управлінського впливу з боку керуючої системи на керовану систему в організаційно-правовій безпеці для переведення останньої в бажаний стан.

Враховуючи множину підходів щодо виокремлення конкретних функцій управління в контексті організаційно-правової безпеки, варто запропонувати їх зміст та сутність.

Першочерговою та основоположною $є$ функція прогнозування. Вона включає аналіз зовнішнього й внутрішнього середовища на предмет попереднього виявлення загроз, аналіз існуючих закономірностей, розробку прогнозів і сценаріїв розвитку у запропонованих сфрерах розробленої ментальної карти інтересів, потреб і цінностей зацікавлених сторін. Важливість цієї функції полягає у створенні інформаційного поля подальшої реалізації процесу управління організаційноправовою безпекою суб'єктів аграрного бізнесу. На основі виявлених тенденцій розробляються можливі сценарії розвитку подій, оцінюється вірогідність їх настання та визначаються впливи найбільш потужних чинників на протікання процесів діяльності підприємства. Всі чинники впливу аналізуються за їх природою відносно можливості несприятливого тиску на організаційно-правову безпеку підприємства.

Ґрунтуючись на отриманих результатах реалізується функція планування, яка полягає у визначенні заходів недопущення впливу загроз на організаційно-правову безпеку підприємства із встановлення строків їх впровадження, виокремлення бюджету на покриття витрат для реалізації зазначених заходів, а також створення додаткового резерву при настанні несприятливих ризиків, які спричиняють втрати. На етапі планування здійснюється оцінка ефективності й доцільності витрат на організацію й забезпечення функціонування системи організаційно-правової безпеки на підприємстві. В ході реалізації функції планування створюються передумови інтеграції системи управління організаційно-правовою безпекою в загальну систему менеджменту підприємства.

Функція організації передбачає розробку положень про здійснення організаційно-правової безпеки на підприємстві із визначенням відповідальних осіб, підрозділу або відділу, закріплення повноважень та узгодженням ієрархії. В ході організації створюється принциповий образ системи управління організаційно-правовою безпекою, який узгоджується із організаційною структурою суб'єкту аграрного бізнесу.

Функція мотивації передбачає гармонізацію системи стимулювання персоналу із значеннями індикаторів ссрер організаційно-правової безпеки й превентивними заходами в рамках стратегії управління. Це передбачає як заохочення кадрів, які демонструють прихильність загальнокорпоративним цінностям в розрізі сфер організаційно-правової безпеки, так і реалізацію санкції в разі порушення умов взаємодії.

Функція контролю передбачає співставлення отриманих результатів реалізованої стратегії із запланованими показниками. Функція регулювання передбачає внесення змін в план управління організаційно-правовою безпекою суб'єктів аграрного бізнесу, перегляд ключових індикаторів оцінки й шляхи комунікації з зацікавленими сторонами. Реалізація функцій управління має здійснюватися відповідно до вищеописаних принципів.

Наступним елементом методологічну базу виступають методи як безпосередньо інструменти реалізації функції управління або як важелів впливу суб'єкта на об'єкт. Найчастіше в контексті управління безпекою підприємства виокремлюють організаційно-адміністративні, економічні та соціально-психологічні методи [20]. В роботі [18] розглядається групування методів на: відносно функції управління (первинних і функції з'єднання) та загальнонаукові. Відносно первинних функцій методи охоплюють стратегічне планування, адміністративні, мотиваційні, оперативного керівництва й контролю. Фактично ці методи відображають реалізацію функцій управління. Відносно функції з'єднання методи поділяються на прийняття рішень та управління комунікаціями. Натомість запропоновані загальнонаукові методи вартують уваги: вони включають емпіричні (спостережень та експериментальні), розумового експерименту та комплексного підходу. Використання загальнонаукових методів обґрунтовано при реалізації функцій прогнозування в управлінні організаційно-правовою безпекою. Емпіричні у формі спостережень та соціологічні дослідження у формі виявлення інтересів, потреб і цінностей дозволяють отримати базове уявлення щодо стану протікання процесів у сферах ментальної карти організаційно-правової безпеки для завчасного виявлення можливості виникнення загроз. Економіко-математичні й статистичні методи дозволяють виявити стійкі закономірності між процесами, які відбиваються в кількісних параметрах. Наприклад пошук взаємозалежності між систематичним порушенням трудової дисципліни та рівнем матеріального стимулювання на підприємстві дозволяє уникнути загроз збоїв в роботі, страйків або інших проявів опортуністичних поведінки, особливо прихованої форми.

Перелік прикладних методів найкращим чином представлений в роботі [21], що дозволяє використовувати запропоновану класифікацію в обґрунтуванні змісту зазначених методів в організаційно-правовій безпеці. Інституційно-правові стосуються запровадження моніторингу стану організаційно-

Вісник Сумського національного аграрного університету 
правової безпеки та її складових, прогнозування загроз, розробки заходів їх недопущення, визначення системи правил і режимів безпеки, розробки інструкцій матеріальної відповідальності й захисту комерційної таємниці, моніторингу законодавства та захисту діяльності від неправомірних рішень регуляторних органів, організації взаємодії із зацікавленими сторонами в рамках контрактних взаємовідносин, захисту прав власності. Адміністративні методи стосуються розробки організаційної структури системи управління організаційно-правовою безпекою із розподілом повноважень і відповідальності, встановлення ієрархії, розробки порядку дій в разі настання загрози, регламентування режимів введення й виведення персоналу, забезпечення недоторканності майна. Економічні методи передбачають впровадження інструментів стимулювання та/або реалізації санкції відносно захисту інтересів, потреб і цінностей зацікавлених сторін в розрізі організаційно-правової безпеки. Зміст даних методів передбачає зміну обсягу матеріальної винагороди від взаємодії із стейкхолдерами.
Організаційно-технологічні методи стосуються впровадження сучасних систем управління якістю серед суб'єктів аграрного бізнесу. Інформаційні методи передбачають захист комерційної інформації, каналів комунікації, методів кодування, систем захисту інформації, її зберігання шляхом використання сучасних технологій та залучення передових фахівців. Соціально-психологічні методи стосується впливу на морально-етичні риси працівників й інших зацікавлених сторін з метою сприйняття цінностей підприємства і виховання прихильності до організаційної культури, що має забезпечувати свідому підтримку заходів захисту організаційно-правової безпеки.

Висновки. Розглянути складові методологічного базису управління організаційно-правовою безпекою мають універсальний характер, що передбачає обов'язковість їх реалізації для успішності досягнення поставлених цілей. Таким чином, розроблений методологічний базис управління організаційно-правовою безпекою виступає потужним інструментом досягнення поставлених цілей суб'єктом управління відносно переведення об'єкта управління у бажаний стан.

\section{Список використаної літератури:}

1. Сьомич М. І. Науково-методологічні положення концепції організаційно-правової безпеки підприємства. / М. І. Сьомич // Вісник Харківського національного технічного університету сільського господарства. - Вип. 202 - «Економічні науки». 2019. - С. 218-233.

2. Гнилицька Л. Теоретико-методологічний інструментарій формування системи забезпечення економічної безпеки підприємства / Л. Гнилицька // Бухгалтерський облік і аудит. - 2013. - № 9. - С. 37-45.

3. Фоміна М. В. Проблеми економічно безпечного розвитку підприємств: теорія і практика: [монографія] / М. В. Фоміна. - Донецьк: ДонДУЕТ, 2005. - 140 с.

4. Основы экономической безопасности (Государство, регион, предприятие, личность) / Под редакцией Е. А. Олейникова. - М.: Бизнес-школа; Интел-Синтез, 1997. - 288 с.

5. Білоусова І. А. Управлінський облік - інформаційна складова системи економічної безпеки: [монографія] / І. А. Білоусова. - К.: Дорадо-Друк, 2010. - 432 с.

6. Ильяшенко С. Н. Составляющие экономической безопасности предприятия и подходы к их оценке / С. Н. Ильяшенко // Актуальні проблеми економіки. - 2003. - № 3(21) - С. 12-19.

7. Кузенко Т. Б. Планування економічної безпеки підприємства в умовах ринкової економіки: автореф. дис. на здобуття наук. ступеня канд. ек. наук: спец. 08.06.01 / Т. Б. Кузенко. - К., 2004. - 18 с.

8. Иванов А. Р. Экономическая безопасность предприятия / А. Р. Иванов, В. А. Шлыков. - М.: Вираж-центр, 1995. 265 c.

9. Козаченко Г. В. Економічна безпека підприємства: сутність та механізм забезпечення: [монографія] / Г. В. Козаченко, В. П. Пономарьов, О. М. Ляшенко. - К.: Лібра, 2003. - 280 с.

10. Мармуль Л.О. Системне управління економічною безпекою аграрних підприємств з урахуванням корпоративних чинників організації діяльності. I $\quad$ Л. О. Мармуль, В. I. Аранчій, Д. C. Apaнчій URL: https://www.pdaa.edu.ua/sites/default/files/nppdaa/10/9.pdf

11. Коробчинський О.Л. Методика формування системи економічної безпеки підприємства / О.Л. Коробчинський // Актуальні проблеми економіки. - №4(94). - 2009. - С.41-45.

12. Ліпкан В. А. Безпекознавтво : [навч. посіб.] / В. А. Ліпкан. - К.: Вид-во Європ. унту, 2003. - 208 с.

13. Мендрул О.Г. Управління вартістю підприємства : [монография] / О.Г. Мендрул. - К. : Вид-во КНЕУ, 2002. - 272 с.

14. Нізяєва С.А. Сучасні проблеми розвитку виноробних підприємств України / С. А. Нізяєва // Вісник Східноєвропейського університету економіки і менеджменту, Черкаси, 2011. - С. 63-69.

15. Филиппова С.В. Трансфертное формирование ключевых компетенций в обеспечении экономической безопасности предприятия / С. В. Филиппова, С.А. Низяева, А.С. Дашковский // «Економіка та менеджмент». Луцький національний технічний ун-т. Зб. наук.пр. серія: Економічні науки - Вип. 9 (34). - Ч.2. - Луцьк: РВВ ЛНТУ, 2012. - С. 190-197.

16. Ляшенко О. М. Концептуалізація управління економічною безпекою підприємства: монографрія / О. М. Ляшенко; 2 ге вид., переробл. - К.: НІСД, 2015. - 348 с.

17. Черняк Г. М. Оцінювання рівня економічної безпеки енергетичних підприємств в умовах євроінтеграції. / Г. М. Черняк // Економічний вісник Національного технічного університету України «Київський політехнічний інститут». - 2015. - № 12. - C. 159-166. 
18. Чорна, М.В. Принципи, функції та методи управління економічною безпекою підприємства роздрібної торгівлі / М. В. Чорна, О. С. Шуміло // Економічна стратегія і перспективи розвитку сфери торгівлі та послуг: зб. наук. пр. / відпов. ред. О.І. Черевко. - Харків: ХДУХТ, 2016. - Вип. 2(24). - С.74-86.

19. Бреус С. В. Принципи управління економічною безпекою закладів вищої освіти в сучасних умовах / С. В. Бреус С. В. Бреус // Економіка та управління національним господарством. Східна Європа: економіка, бізнес та управління. - 2018. - Випуск 6 (17). - С. 56-63.

20. Діденко Є. О. Управління економічною безпекою підприємства на основі формування стратегії його безпечного розвитку / Є. О. Діденко // Формування ринкових відносин в Україні. - К. : НДЕІ, - 2015. № 5 (168). - С. $35-40$.

21. Орлик О. В. Механізм управління фрінансово-економічною безпекою підприємства та його основні складові / О. В. Орлик // Фінансово-кредитна діяльність: проблеми теорії та практики. - 2015. - Вип. 2. - С. 222-232.

Syomych M. I., PhD in Public Administration, Associate Professor, Poltava State Agrarian Academy (Poltava, Ukraine) The methodological basis of management organization and legal security of agricultural business entities.

The article is devoted to the substantiation of the methodological basis for managing the organizational and legal security of agricultural business entities. The understanding of management in terms of cybernetics is considered. The role of stakeholders in the management of organizational and legal security is defined. Approaches to management of economic security of the enterprise are considered: resource-functional, management concerning protection of enterprise interests, harmonization approach, controlling approach, from the standpoint of corporate culture and effective corporate governance. It is determined that the methodological basis is the basis of management. Some general and specific principles of organizational and legal security management have been proposed. The general group includes: principle of legality, systematicity, validity, timeliness, complexity, balance, continuity, economy or economic expediency, effectiveness of management decisions, purposefulness, objectivity, dynamism, adaptability, flexibility, interaction, sufficiency, convergence information, centralization of management, priority.

The specific group includes: activity, continuous monitoring, coordination, integration, variability, adequacy of response, retention of stability, management modeling (organizational modeling, optimal comparison of centralization and decentralization), employee participation in management, priority of preventive measures, specialization, expertise, differentiation, cyclicality, coherence of interests.

The management functions of the organizational and legal security are offered: forecasting, planning, organization, motivation, control. The content of methods within the methodological framework, which include organizational, administrative, economic, social and psychological, are considered and substantiated. General scientific and applied methods are also distinguished. Applied methods are divided into institutional legal, administrative, economic, organizational and technological, information, social and psychological.

Key words: organizational and legal security, subjects of agrarian business, methodological basis, methods, functions, principles.

Дата надходження до редакції: 21.10.2019 р. 